\title{
Problems and Solutions in the Operation of Belt Conveyors in the River Port RTC Luka Leget
}

\author{
Dragan Živanić ${ }^{1 *}$, Atila Zelić ${ }^{1}$, Mirko Katona ${ }^{1}$ \\ ${ }^{1}$ Faculty of Technical Sciences/Department of Mechanization and Design Engineering, University of Novi Sad, Novi Sad \\ (R. Serbia) \\ The paper presents a case study of gravel transshipment in RTC Luka Leget in Sremska Mitrovica, R. Serbia. \\ Problems that led to the incorrect operation of conveyors used in the transshipment of gravel from barges to the separation \\ plant were analyzed. They included activation the safety switch of the conveyor drive, backward movement of the material \\ on the belt, fracture of the connection tension pulley - axle, etc. It was found that ignorance of the actual force in the \\ conveyor belt leads to most of the problems and the need of a solution for this problem was highlighted. At the end, \\ proposed solutions were given in order to establish the normal operation of the plant and to prevent delays in gravel \\ transshipment.
}

Keywords: Belt conveyors, River port, Gravel separation

\section{INTRODUCTION}

The characteristic of machines and devices with continuous operation is the movement of material without stopping in order to accept and dispose material [1]. Machines and devices for continuous transport are used in all areas of economic activity, from administration to work in mining, both for the transport of materials and for the transfer of people [2]. The most common device for continuous transport is the belt conveyor due to its technoeconomic characteristics:

- transport capacity from 50 to $25.000 \mathrm{t} / \mathrm{h}$;

- the length of the conveyor ranges from a few meters to about 15 kilometers with the possibility of continuing the length;

- transport speed goes from 0,8 to $8 \mathrm{~m} / \mathrm{s}$.

Belt conveyors are used in agriculture, process industry, mining, in transhipment of bulk material in ports, etc. Their role as a device of continuous transport has become very important in the era of Industry 4.0 due to the possibility of full automation of production and transport of goods $[3,4,5,6,7]$.

During the first six months of 2019, 6,28 million tons of cargo was transhipped in ports in the Republic of Serbia. Gravel, sand and stone aggregates accounted for the largest share of transhipped cargo, accounting for $21 \%$ of transhipment. Among the five most successful ports for the transport of inland waterways in the Republic of Serbia is RTC Luka Leget from Sremska Mitrovica, R. Serbia [9]. Within the port, there is a gravel pit where transhipment of Drina gravel from barges to the mainland is performed. Gravel handling capacity is about $200 \mathrm{t} / \mathrm{h}$ [10].

\section{THE PROCESS OF GRAVEL TRANSHIPMENT}

One bucket conveyor and four belt conveyors are involved in the process of transshipment of gravel in the Leget port. The bulk density of gravel is a variable category that depends on the moisture content of the mass. Therefore, it ranges from 1,45 to $1,95 \mathrm{t} / \mathrm{m}^{3}$ [2]. Gravel barges are fixed to the loading ship on which the bucket conveyor and one belt conveyor are placed, Figure 1.

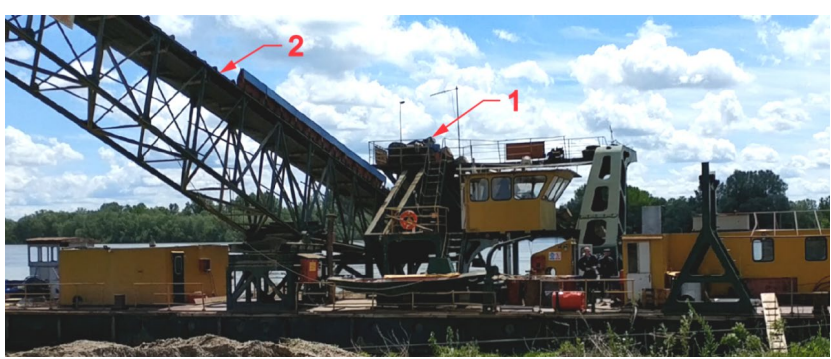

Figure 1. Transshipment ship: bucket conveyor - 1; belt conveyor -2

The bucket conveyor picks up the material from the barge and reloads it on a belt conveyor which unloads the material into the loading hopper, Figure 2.

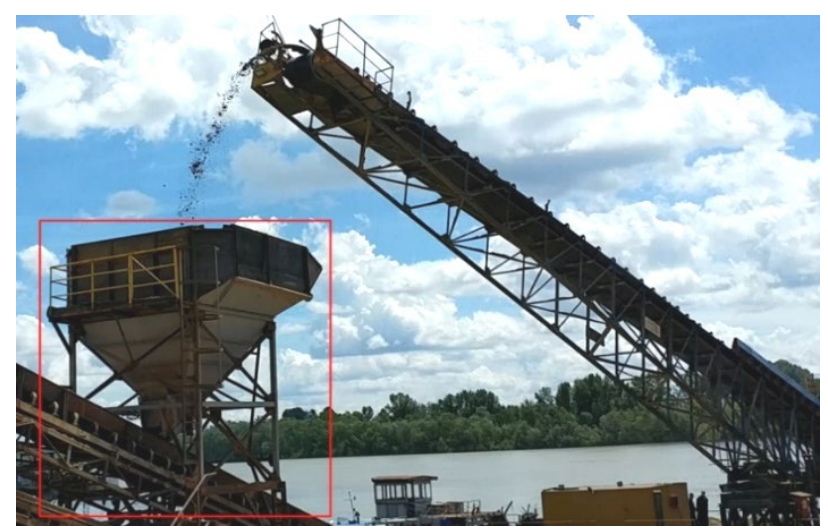

Figure 2. Unloading of material into the loading hopper

From the loading hopper, the material reaches the system of three belt conveyors, Figure 3 .

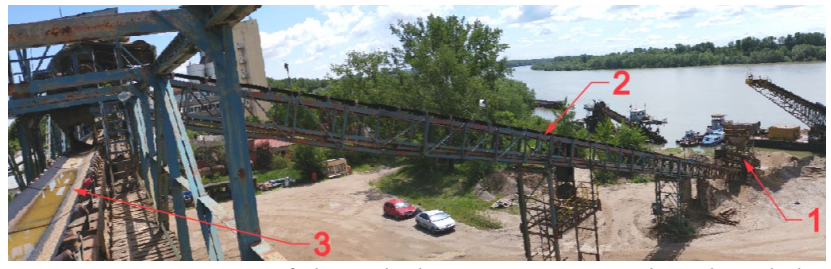

Figure 3. System of three belt conveyors: inclined mobile conveyor - 1, inclined conveyor - 2, reversible conveyor - 
The inclined mobile conveyor forms one unit with the loading hopper. They can move depending on the water level in the river Sava. From the inclined mobile conveyor, the material is loaded to the inclined conveyor. From the inclined conveyor, the material is transferred to the reversible conveyor. Its characteristic is that it can transport material to the left or to the right, depending on the needs. It can also move translatory along the structure. From the reversible conveyor, the material is loaded to a gravel separation plant, Figure 4.

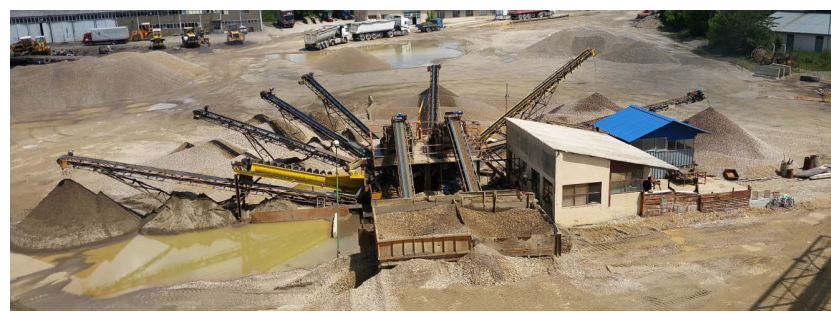

Figure 4. Gravel separation plant

\section{THE DIAGNOSIS OF PROBLEMS IN THE OPERATION OF BELT CONVEYORS}

In the process of gravel transhipment in the RTC Luka Leget, several problems and dangers occur in correlation with three belt conveyors shown in Figure 3:

1. When transporting wet gravel, the safety switch of the electric motor is activated and interrupts the inclined mobile conveyor operation. This problem is especially dangerous when it happens during night work because the operator on the transshipment ship cannot see that the operation of the Inclined mobile conveyor has been stopped. Then there is an accumulation of material in the loading hopper and scattering all around the conveyor.

2. The material slides backwards on the conveyor belt when transporting wet gravel.

3. The connection between the tension pulley and the axle of the Inclined moving conveyor breaks relatively often.

4. Material is often stick to the wall in the loading hopper.

5. When transporting wet gravel, the belt on the drive pulley of the inclined conveyor slips.

6. The belt moves sideways on all three conveyors.

In order to determine the essence of the problem, an expert review and analysis of the three mentioned conveyors was performed. At the beginning, the number of revolutions per minute of drive pulleys was measured in order to determine the speed of material transport, and an inspection of the drive electric motors was performed in order to collect information about characteristics of motors. The number of revolutions per minute of drive pulleys was determined using a laser non-contact tachometer, Figure 5. Before the measurement, the tachometer was calibrated using a rotational mass of a known number of revolutions. Each measuring device changes its characteristics over time and there is no ideal measurement. Therefore, it is necessary to perform device calibrations $[11,12]$. Based on the measured number of revolutions and the diameter of pulleys, the speed of material transport was determined. Then, the geometrical characteristics of conveyors were measured.

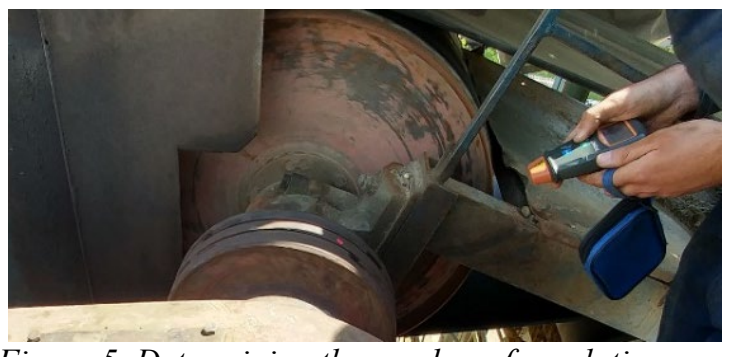

Figure 5. Determining the number of revolutions per minute of drive pulleys

The following characteristics of conveyors have been determined:

1. Inclined mobile conveyor - the length of the conveyor is $17,6 \mathrm{~m}$ with a slope of $20^{\circ}$. The material transport speed is $1,66 \mathrm{~m} / \mathrm{s}$. Tensioning is done by means of threaded spindles which are placed on the lower tension pulley. The power of the electric drive motor is $11 \mathrm{~kW}$.

2. Inclined conveyor - the length of the conveyor is $55,5 \mathrm{~m}$ with a slope of $20^{\circ}$. The material transport speed is $1,63 \mathrm{~m} / \mathrm{s}$. Tensioning is done using a tension weight placed in the upper half of the conveyor. The power of the electric drive motor is $30 \mathrm{~kW}$.

3. Reversible conveyor - the length of the conveyor is $33,7 \mathrm{~m}$, it is horizontal. The material transport speed is $1,58 \mathrm{~m} / \mathrm{s}$. Tensioning is done with threaded spindles. The power of the electric drive motor is $7,5 \mathrm{~kW}$.

The condition of conveyor elements was examined and for each of the conveyor additional problems were identified on the premise.

As for the inclined mobile conveyor, it has been determined that the belt cleaner on the return side is not in use. A large amount of sticked material was noticed on return idlers and a large wear of the conveyor belt was determined, Figure 6. Also, it was determined that a certain number of support idlers do not rotate, which introduces additional resistance into the system and wears the belt.
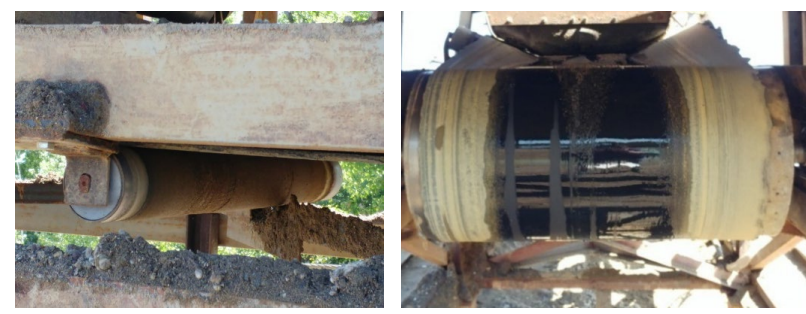

Figure 6. Sticked material on return idlers and worn belt

Next, the connection between the tension pulley and the axle was examined. It is created by welding the pulley to the axle with additional stiffeners, Figure 7.

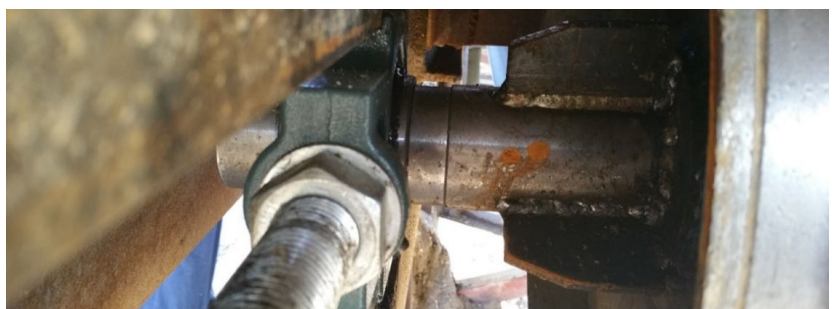

Figure 7. Connection between the tension pulley and the axle 
It has been determined that there are guides for loading the material along the entire length of the conveyor. The guides touch the belt along its entire length and create additional resistance when the belt moves.

As for the inclined conveyor, it was determined that idlers for belt guiding, Figure 8, were damaged, and that there was no belt cleaner leading to the collection of material on return idlers. The dimensions of the tension concrete weight were measured and based on the specific density of concrete, the mass of the tension weight of 700 $\mathrm{kg}$ was determined. Also, it was determined that a certain number of support idlers do not rotate, which introduces additional resistance into the system and wears the belt.
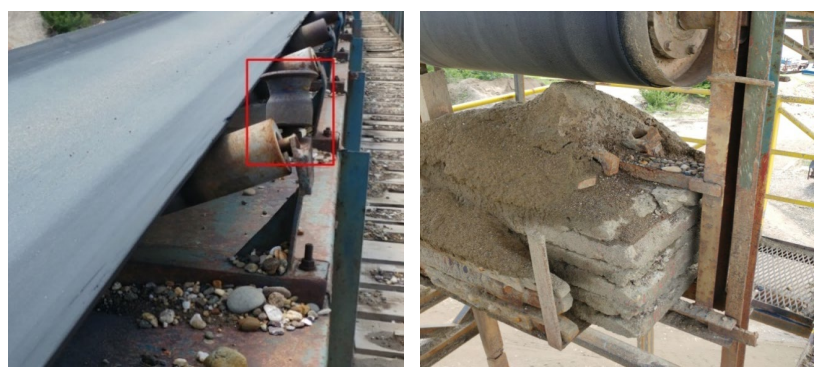

Figure 8. Damaged guide idler and tension weight

As for the reversible conveyor, it was determined that it does not have a belt cleaner, which leads to the collection of material on return idlers. The danger of approaching the drive mechanism has been noticed. Namely, the construction of the conveyor is such that it has two paths next to the conveyor that are not interconnected by an adequate pass, Figure 9. In order to approach the drive mechanism, it is necessary to jumps from the first to the second path.

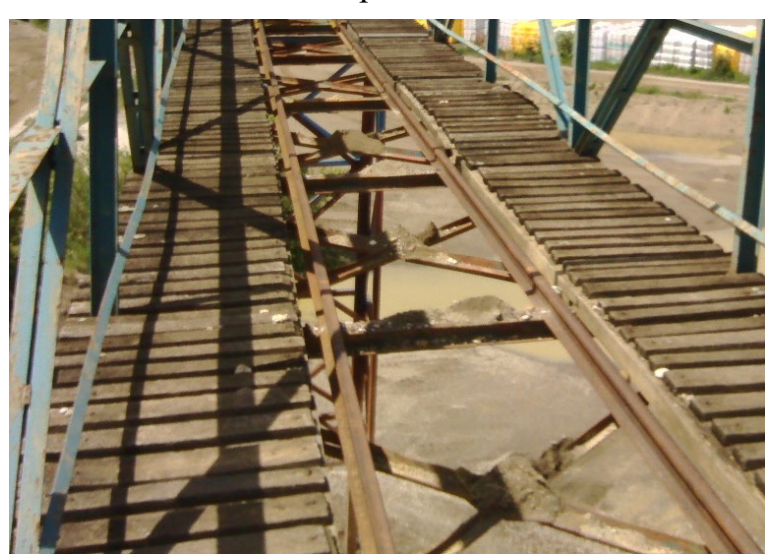

Figure 9. The gap between two conveyor paths

\section{THE CALCULATION OF BELT CONVEYORS}

Upon completion of the expert review, the calculation of conveyors was made according to [2] in order to determine the required power to drive these three conveyors. The calculation was done to see if the existing electric motors are the cause of the problems that occur, i.e., whether the drive forces are insufficient for the occurring resistances. The most difficult case was used, i.e., a gravel density of $1,95 \mathrm{t} / \mathrm{m}^{3}$ was taken.

\subsection{The inclined mobile conveyor}

The scheme of the inclined mobile conveyor is given in Figure 10. It shows the characteristic points that were used in the calculation by the outline calculation method.

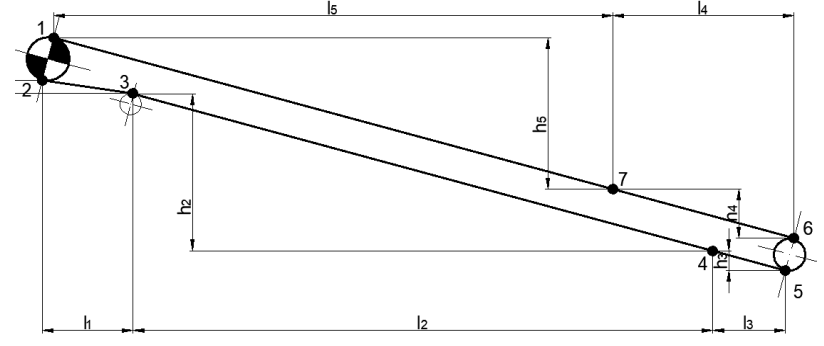

Figure 10. Scheme of the inclined mobile conveyor with marked characteristic points

Table 1 shows the results of the calculation of the inclined mobile conveyor. It was done with three values of the coefficient of belt load $k_{2}-0,2 ; 0,54$ and 0,7 . The load coefficient of the belt determines what percentage of the material is on the belt in relation to the theoretical maximum amount. Then with two values of the coefficient of resistance to movement $c_{r}$ - for work in unheated environment of normal humidity and with small amounts of deposits, and for work in unheated environment in the outside air with the presence of more deposits, increased humidity and other difficult factors affecting the movement of the belt and bearing operation. Also, the position of the conveyor depending on the water level of the river through dimension $l_{4}$ was taken into account.

Table 1. Results of the calculation of the inclined mobile conveyor

\begin{tabular}{|c|c|c|c|c|c|c|c|c|c|c|c|c|}
\hline$v$ & \multicolumn{10}{c|}{$1,66 \mathrm{~m} / \mathrm{s}$} \\
\hline$\rho$ & \multicolumn{10}{|c|}{$1,95 \mathrm{t} / \mathrm{m}^{3}$} \\
\hline$k_{2}$ & \multicolumn{3}{|c|}{0,2} & \multicolumn{3}{c|}{0,54} & \multicolumn{3}{c|}{0,7} \\
\hline$c_{r}$ & 0,04 & 0,025 & 0,04 & 0,025 & \multicolumn{3}{c|}{0,04} & 0,025 \\
\hline$l_{4}[\mathrm{~m}]$ & 2 & 10 & 2 & 10 & 2 & 10 & 2 & 10 & 2 & 10 & 2 & 10 \\
\hline$P[\mathrm{~kW}]$ & 4 & 2,9 & 3,7 & 2,6 & 7,5 & 4,7 & 7 & 4,3 & 9,2 & 5,5 & 8,6 & 5 \\
\hline $\begin{array}{c}S_{\max } \\
{[\mathrm{kN}]}\end{array}$ & 3,4 & 2,5 & 3,2 & 2,2 & 6,4 & 4 & 6 & 3,6 & 7,8 & 4,7 & 7,3 & 4,3 \\
\hline$S_{t}[\mathrm{kN}]$ & 2,4 & 1,6 & 2 & 1,3 & 4,6 & 2,7 & 4,3 & 2,5 & 5,7 & 3,3 & 5,3 & 3 \\
\hline $\begin{array}{c}Q_{v} \\
{\left[\mathrm{~m}^{3} / \mathrm{h}\right]}\end{array}$ & 37 & 37 & 37 & 37 & 101 & 101 & 101 & 101 & 131 & 131 & 131 & 131 \\
\hline $\begin{array}{c}Q_{m} \\
{[\mathrm{t} / \mathrm{h}]}\end{array}$ & 73 & 73 & 73 & 73 & 197 & 197 & 197 & 197 & 255 & 255 & 255 & 255 \\
\hline
\end{tabular}

\subsection{The inclined conveyor}

The scheme of the inclined conveyor is given in Figure 11. It shows the characteristic points that were used in the calculation by the outline calculation method.

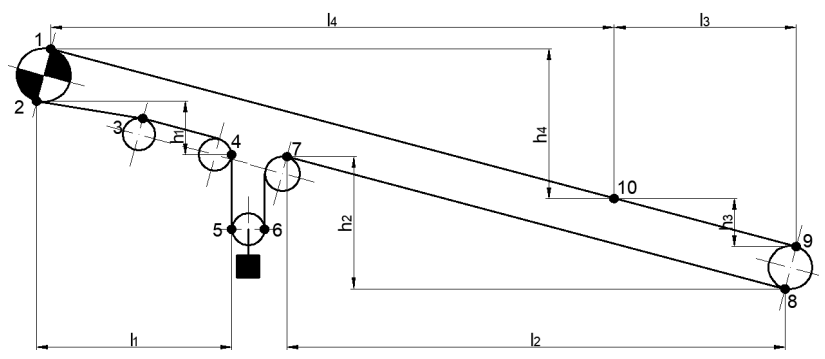

Figure 11. Scheme of the inclined conveyor with marked characteristic points

Table 2 shows the results of the calculation for the inclined conveyor. Here, as with the previous conveyor, different coefficients of load, resistance to movement, as well as the position of the previous conveyor through dimension $l_{4}$ are taken into account. 
Table 2. Results of the calculation of the inclined conveyor

\begin{tabular}{|c|c|c|c|c|c|c|c|c|c|c|c|c|}
\hline$v$ & \multicolumn{10}{c|}{$1,63 \mathrm{~m} / \mathrm{s}$} \\
\hline$\rho$ & \multicolumn{10}{|c|}{$1,95 \mathrm{t} / \mathrm{m}^{3}$} \\
\hline$k_{2}$ & \multicolumn{3}{|c|}{0,2} & \multicolumn{1}{c|}{0,54} & \multicolumn{5}{c|}{0,7} \\
\hline$c_{r}$ & 0,04 & 0,025 & \multicolumn{1}{c|}{0,04} & \multicolumn{2}{c|}{0,025} & \multicolumn{2}{c|}{0,04} & \multicolumn{2}{c|}{0,025} \\
\hline $\begin{array}{c}l_{4} \\
{[\mathrm{~m}]}\end{array}$ & 2 & 15 & 2 & 15 & 2 & 15 & 2 & 15 & 2 & 15 & 2 & 15 \\
\hline $\begin{array}{c}P \\
{[\mathrm{~kW}]}\end{array}$ & 6,4 & 5,2 & 5,7 & 4,5 & 14,1 & 11 & 13,1 & 10,1 & 17,7 & 13,8 & 16,5 & 12,8 \\
\hline $\begin{array}{c}S_{\max } \\
{[\mathrm{kN}]}\end{array}$ & 5,6 & 4,5 & 5 & 3,9 & 12,5 & 9,8 & 11,6 & 9 & 15,7 & 12,3 & 14,7 & 11,3 \\
\hline $\begin{array}{c}S_{t} \\
{[\mathrm{kN}]}\end{array}$ & 3,5 & 2,6 & 3 & 2,2 & 8,8 & 6,7 & 8 & 6 & 11,2 & 8,5 & 10,4 & 7,9 \\
\hline $\begin{array}{c}Q_{v} \\
{\left[\mathrm{~m}^{3} / \mathrm{h}\right]}\end{array}$ & 36 & 36 & 36 & 36 & 99 & 99 & 99 & 99 & 128 & 128 & 128 & 128 \\
\hline $\begin{array}{c}Q_{m} \\
{[\mathrm{t} / \mathrm{h}]}\end{array}$ & 71 & 71 & 71 & 71 & 193 & 193 & 193 & 193 & 250 & 250 & 250 & 250 \\
\hline
\end{tabular}

\subsection{The reversible conveyor}

The scheme of the reversible conveyor is given in Figure 12. It shows the characteristic points that were used in the calculation by the outline calculation method.

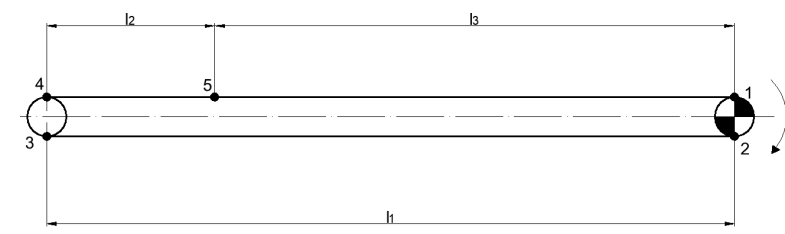

Figure 12. Scheme of the reversible conveyor with marked characteristic points

Table 3 shows the results of the reversible conveyor calculation. Here, as with the previous conveyor, different load and resistance to movement coefficients are taken into account.

Table 3. Results of the calculation of the reversible conveyor

\begin{tabular}{|c|c|c|c|c|c|c|}
\hline$v$ & \multicolumn{6}{|c|}{$1,58 \mathrm{~m} / \mathrm{s}$} \\
\hline$\rho$ & \multicolumn{6}{|c|}{$1,95 \mathrm{t} / \mathrm{m}^{3}$} \\
\hline$k_{2}$ & \multicolumn{2}{|c|}{0,2} & \multicolumn{2}{|c|}{0,58} & \multicolumn{2}{c|}{0,7} \\
\hline$c_{r}$ & 0,04 & 0,025 & 0,04 & 0,025 & 0,04 & 0,025 \\
\hline$P[\mathrm{~kW}]$ & 1,5 & 1 & 2,2 & 1,4 & 2,4 & 1,5 \\
\hline$S_{\max }[\mathrm{kN}]$ & 1,9 & 1,2 & 2,6 & 1,7 & 2,8 & 1,8 \\
\hline$S_{t}[\mathrm{kN}]$ & 2,3 & 1,5 & 3,1 & 2 & 3,4 & 2,2 \\
\hline$Q_{v}\left[\mathrm{~m}^{3} / \mathrm{h}\right]$ & 40 & 40 & 118 & 118 & 142 & 142 \\
\hline$Q_{m}[\mathrm{t} / \mathrm{h}]$ & 79 & 79 & 231 & 231 & 278 & 278 \\
\hline
\end{tabular}

\section{ANALYSIS OF OBTAINED RESULTS AND PROPOSED SOLUTIONS}

Regarding the first mentioned problem of activating the safety switch of the electric motor of the inclined mobile conveyor, based on the results obtained in the previous chapter, it can be concluded that all three conveyors have excess power even in the most difficult case as shown in Figure 13.
It can be concluded that the load that occurs due to the transport of materials, even in the most difficult conditions, should not cause the activation of the safety switch. However, if it is looked at the bigger picture and if the second problem is included in the analysis of the problem - the material slipping backwards on the belt, it is clear that this phenomenon affects the appearance of additional load. The reason for the slippage of the material, especially when it is very wet, is that the angle of inclination of the conveyor is $20^{\circ}$, and the maximum allowed angle of inclination during the transport of gravel is $17^{\circ}$ [2]. Also, if the third problem is taken into account the break of the connection between the tension pulley and the axle of the inclined mobile conveyor, it can be concluded that there is a third category of load other than the load due to material transport and material slippage. Certainly, the construction of the connection between the tension pulley and the axle by welding is not an adequate solution, but the fracture itself, which occurs even after the addition of stiffening, indicates that there is a load that has not been considered so far. In order to get to the root of the problem, the staff that serves the transporter was interviewed. When asked how they maintain the work of the conveyor, they answered that as soon as the belt starts to move laterally from the direction of transport, they apply more tension to the belt through the tensioning mechanism. Based on that, it was concluded that this third category of load is due to the unnecessary tensile force that was introduced into the system. Namely, when the conveyor is prepared for the first start, it is tensioned to the optimal value that enables proper operation. A common mistake during operation is that operators attribute all the problems in the operation of the belt to its elongation and the only solution they apply is to apply more tension to the belt. This introduces an additional unnecessary load that is relatively invisible to the naked eye of the observer.

A big problem, if not the biggest one, in the operation of belt conveyors is the ignorance of the real force in the belt during operation. The results obtained by calculation according to [2] are the results obtained on the basis of empirical formulas. These empirical formulas take into account a large number of factors, but it is not possible to cover all the factors that affect work during real working conditions. It is crucial that the theoretical knowledge acquired within the framework of conventional academic courses is expanded and deepened through their application in practical work [13]. So far, no solution for live monitoring of the state of force in the belt has been implemented. However, there is a solution to monitor the force with which the system is tensioned. Since it is previously said that tensioning by means of a threaded spindle is applied to this conveyor, it is possible to process the threaded spindle in order to apply strain gauges. Such a solution was applied in $[14,15]$ and it is shown in Figure 14.

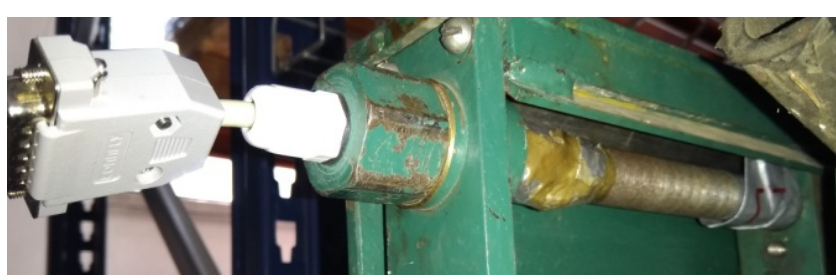

Figure 14. Strain gauges applied to the threaded spindle 
The introduction of this system would make it possible to monitor with how much force the belt is tensioned and this force could be kept constantly within the limits of the required calculated tensile force.

The problem of material slipping backwards cannot be changed by reducing the angle of inclination of the conveyor as this would mean a complete reconstruction of the conveyor, but it is necessary to replace the smooth belt with the ribbed belt. An example of a belt with ribs is shown in Figure 15.

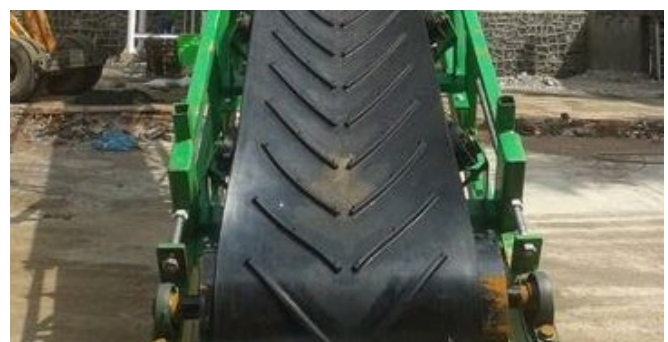

Figure 15. Example of a ribbed belt

As for the fracture of the connection between the tension pulley and the axle, certainly the pressure on that connection would be reduced by removing the excess tension force, but it is necessary to apply a technically correct solution via the key shown in Figure 16. There are other ways to achieve the connection between the drive pulley and shaft $[16,17]$, but for a robust construction like this, the key connection is a solution that is completely satisfactory [18].

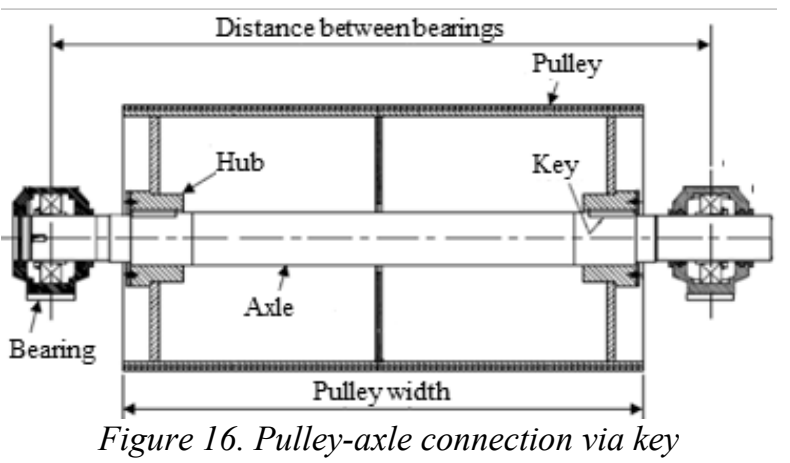

As for the fourth problem - that the material is sticked to the walls of the loading hopper of the Inclined mobile conveyor, it is necessary to place a vibrating device on the hopper. The role of vibrators is to reduce the cohesion between transported material and the walls of the hopper. Also, they reduce cohesion between material particles. By doing that, they increase the material flow [19]. Adding a vibrating device to the hopper would further aid in loading the material because it would allow dosing of the amount of material being loaded onto the inclined mobile conveyor. An example of such a solution is given in Figure 17.

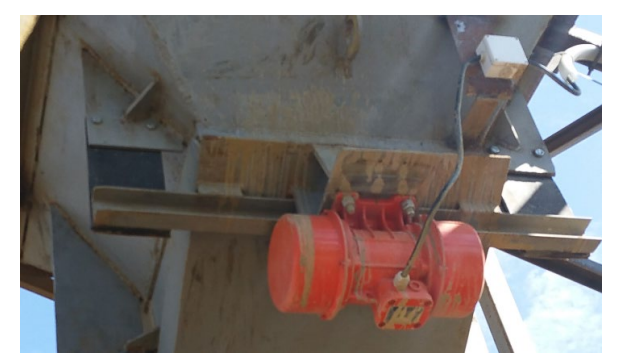

Figure 17. Vibrating device on the loading hopper
By calculating the inclined conveyor, it was found that the required tensile force is $11,2 \mathrm{kN}$. Taking into account the additional resistances that occur with weight guides, it was concluded that a weight of $1450 \mathrm{~kg}$ is required for the conveyor to function properly. As a weight of $700 \mathrm{~kg}$ was placed on the inclined conveyor, it was determined that the cause of the belt slip on the drive pulley was a light weight and that it was necessary to add concrete plates with a total mass of $750 \mathrm{~kg}$ in order for the conveyor tensile force to be at the required level.

There are several reasons for the belt lateral movement on all three conveyors:

- difference in rotation resistance of support idlers;

- lack of cleaning of the belt on the return side;

- lack of training idlers;

- damaged guide idlers.

In the field, it was noticed that a certain number of support idlers on conveyors was replaced, while the rest of idlers remained unchanged. That was a mistake because older rollers have a higher resistance to rotation due to degradation than the new ones, which leads to the movement of the belt to the side. If it is economically feasible, it is recommended to replace all support idlers on the conveyor at the same time.

The lack of cleaning of the belt on the return side is a big problem because the material sticks to return idlers. The material does not stick evenly to idlers, which additionally causes the belt to move sideways, Figure 18 .

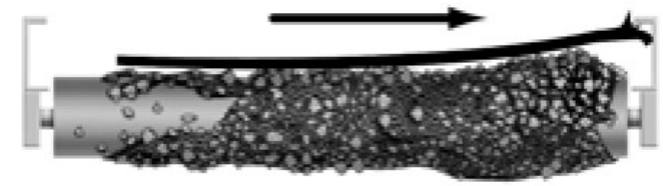

Figure 18. Movement of the belt due to the sticked material on the return idler

On the inclined and reversible conveyor, it is necessary to install a cleaner in the shape of a springloaded knife, shown in Figure 19.

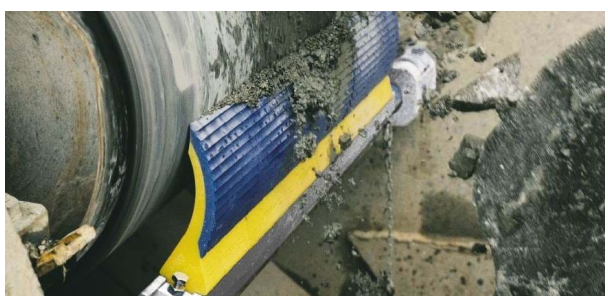

Figure 19. Smooth belt cleaner

However, the before mentioned cleaner cannot be mounted on the inclined mobile conveyor because it is recommended to replace the smooth belt with a ribbed belt. Figure 20 shows a brush-shaped cleaner used for ribbed belts.

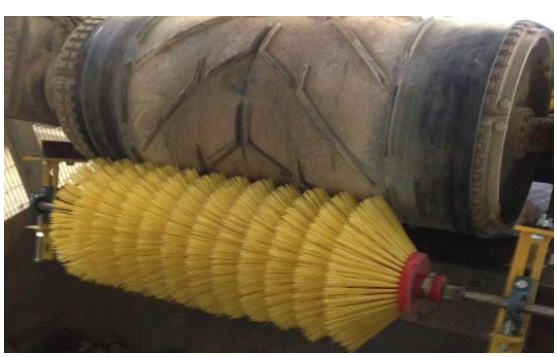

Figure 20. Rib belt cleaner 
Placing training idler stacks, Figure 21, would prevent the belt from moving to the side. They function in such an order that when the belt moves laterally, they rotate around the central axis and due to the difference in the directions of the circumferential speed of the idler and the movement of the belt, a speed component appears that returns the belt to the basic direction [2].

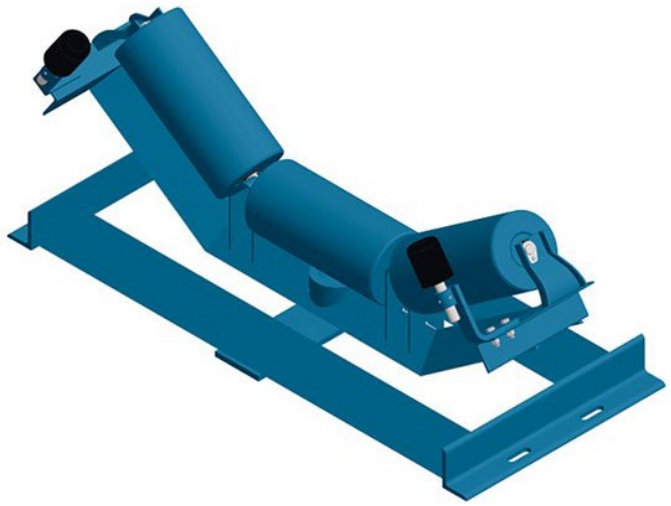

Figure 21. Training idler

As for damaged elements on all conveyors, their replacement is recommended. A major economic expense is the replacement of conveyor belts. Therefore, it is recommended only for the Inclined mobile conveyor, because its condition is the most critical. Belts are made according to standards [20] and are tested to determine their characteristics [21]. It is very important that the belt is chosen correctly in order for its working life to be as long as possible due to the share in the price of the entire conveyor. Problems such as those described here where the material guides on the Inclined mobile conveyor were positioned so as to damage the belt, should be avoided as they cause unnecessary maintenance costs.

As mentioned earlier, access to the drive at the reversible conveyor is very dangerous because it is necessary to jump from one path to another. There is a risk of falling and death at that place, as the conveyor is at a high altitude. This problem can be solved by placing platforms for the passing from one side to the other at both ends of the conveyor route, Figure 22.

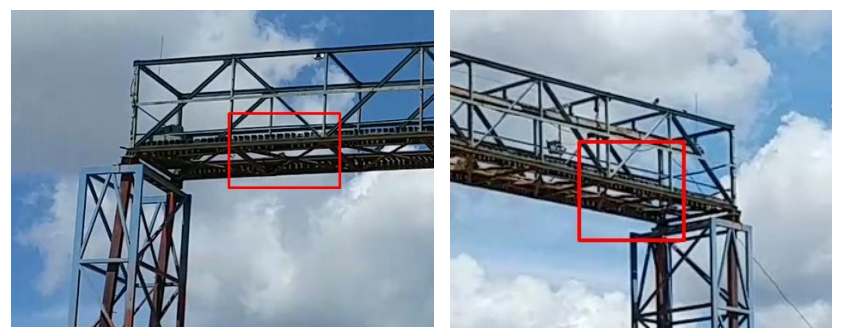

Figure 22. Places for platforms on the conveyor route

It is necessary to set up two platforms due to the characteristic of the conveyor to move along the route depending on the place of unloading. Platforms should have the ability to lift so that the conveyor can move to the end of the route. A proposal for a possible solution for the platform is given in Figure 23. In modern times, the priority for engineers are health and safety measures. In the legislation of developed countries, health and safety measures are placed on the top of the regulations concerning human labor. Essential safety measures concerning material and people transport devices can be seen in $[22,23,24,25,26,27]$.

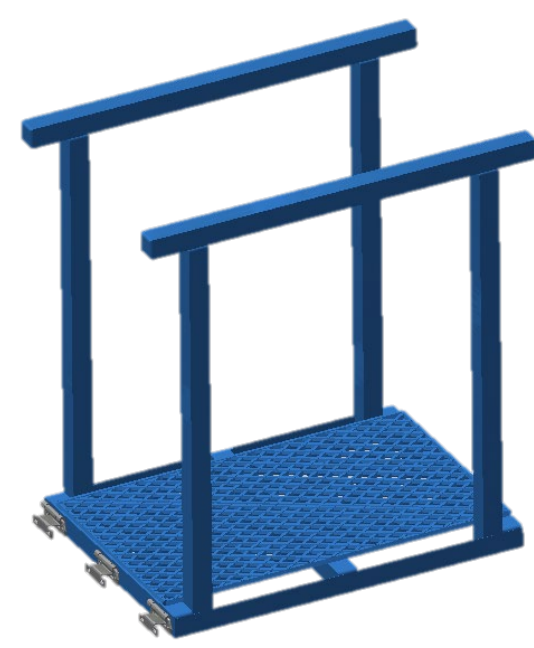

Figure 23. Platform proposal

\section{CONCLUSION}

The paper presents a gravel transhipment line in the river port in Sremska Mitrovica. The problems that arose during the exploitation were pointed out and a proposal of measures for solving them was given. Part of the problem stems from improper line handling, but part of the problem stems from poorly designed solutions. It was determined that due to the higher inclination of the belt conveyors than allowed, the material is moves backwards during transport. The proposed solution for this is to replace the smooth belt with ribbed belt. It was then found that too much tensile force was applied to one conveyor which led to problems with the operation of the drive group, while on the other conveyor the tensile force was too low to establish proper operation. Also, a very degraded condition of some components was noticed, the replacement of which is recommended. It was concluded that the main problem of all the above is the ignorance of the real force in the belt during the operation of the belt conveyor. The direction of further research should be to work on the design of a system that would enable the monitoring of the force in the belt during exploitation.

\section{REFERENCES}

[1] D. Živanić, N. Ilanković, S. Bojić, D. Radaković, A. Zelić, „The Logistical Approach to the Analysis, Modelling and Simulation of Material Flow", LIM Logisztika - Informatika - Menedzsment, Vol. 4(1), pp. 43-50, (2019)

[2] D. Živanić, „Neprekidni i automatizovani transport“ skripta, University of Novi Sad, FTN Novi Sad, Novi Sad (Serbia), (2020)

[3] N. Ilanković, D. Živanić, A. Zelić, M. Guban, L. Szabo, „Basic Principles of Industry 4.0 as the Foundation for Smart Factories and Digital Supply Networks", Proceedings of International Conference „Sustainable Logistics 4.0“, Beograd (Serbia), 5th November 2019, pp. 59-64, (2019)

[4] D. Živanić, N. Ilanković, A. Zelić, „The Logistical Approach to the Design of Transportation Systems“, Proceedings of International Conference „Sustainable Logistics 4.0“, Beograd (Serbia), 5th November 2019, pp. 71-76, (2019) 
[5] L. Szabo, M. Guban, A. Zelić, N. Ilanković, T. David, „Identification Methods Applied by Logistics Service Providers in Zala County“, Kutatói innovációk Válogatás egy kutatási projekt eredményeiből az EFOP 3.6.1-16-2016-00012 számú projekt keretében végzett kutatásokból, Budapesti Gazdasági Egyetem, Budapest (Hungary), pp. 23-45, (2019)

[6] N. Ilanković, D. Živanić, A. Zelić, „Augmented Reality in Order-picking Processes - Advantages and Disadvantages“, LIM - Logisztika - Informatika Menedzsment, Vol. 5(1), pp. 4-12, (2020)

[7] N. Ilanković, A. Zelić, M. Guban, L. Szabo, „Smart factories - The Product of Industry 3.0“, Prosperitas, Vol. 7(1), pp. 19-30, (2020)

[8] https://bit.ly/39jVeIq - accessed on 20. 11. 2020.

[9] https://bit.ly/3acmgRA - accessed on 20. 11. 2020.

[10] M. Katona „Analiza mogućnosti rada i proračun trakastih transportera u liniji pretovara šljunka“ bachelor thesis, University of Novi Sad, FTN Novi Sad, R. Serbia, (2019)

[11] N. Ilanković, D. Živanić, A. Zelić, M. Đukić, „Project of Reconstruction of the Device Df 0.2 Used for Calibration of Dynamometers", Proceedings of the International Scientific Conference „ETIKUM 2018“, Novi Sad (Serbia), 6-8 December 2018, pp. 17-20, (2018)

[12] N. Ilanković, B. Stojić, D. Ružić, N. Tepavac, D. Živanić, „Usage of the Arduino Microcontroller on the Student Hybrid Vehicle Hermes“, Mašinstvo, Vol. 16(3-4), pp. 53-62, (2019)

[13] B. Stojić, D. Ružić, Z. Ivanović, E. Adžić, N. Ilanković, „Light Hybrid-electric Vehicle as Educational and Research Plaftform“, Proceedings of the 7th International Scientific Congress ,Motor Vehicles and Motors 2018 - Ecology - Vehicle Road Safety - Efficiency“, Kragujevac (Serbia), 4-5 October 2018, pp. 377-382, (2018)

[14] D. Živanić, A. Gajić, A. Zelić, N. Ilanković, „Flat Belt Feeder Regulation Possibilities“, Proceedings of the 13th International Scientific Conference „MMA 2018 - Flexible Technologies“, Novi Sad (Serbia), 2829 September 2018, pp. 351-354, (2018)

[15] N. Ilanković, D. Živanić, „Analysis of Influential Parameters of Measurement Accuracy with the Belt Feeder", Zbornik radova Fakulteta tehničkih nauka, Vol. 23(11), pp. 1897-1900, (2018)

[16] D. Živanić, N. Bodrožić, N. Ilanković, A. Zelić, „Posibilities of Belt Conveyors Automated Design“, Proceedings of the International Conference „LIM 2020“, Zalaegerszeg (Hungary), 25. September 2020, pp. 16-21, (2020)

[17] N. Bodrožić, D. Živanić, N. Ilanković, „Automated Design of Belt Conveyors with Supporting Structure of Aluminium Profiles“, Zbornik radova Fakulteta tehničkih nauka, Vol. 25(11), pp. 1863-1866, (2020)

[18] M. Vasić, Z. Đorđević, M. Blagojević, „Stress-Strain Analysis of Conveyor Drive Pulley Shaft", IMK 14 -
Research \& Development, Vol. 25(3), pp. 69-74, (2019)

[19] D. Živanić, N. Ilanković, A. Zelić, „Possibilities of Material Flow Propagation Through Conveyor Loading Devices", Proceedings of the 7th International Conference „Transport and Logistics“, Niš (Serbia), 6th December 2019, pp. 65-70, (2019)

[20] N. Ilanković, D. Živanić, M. Katona, „Analysis of Axial Tests of Conveyor Belt Samples“, Mašinstvo, Vol. 17(3-4), pp. 75-80, (2020)

[21] M. Katona, N. Ilanković, D. Živanić, „Design of the Device for Testing Conveyor Belts“, Zbornik radova Fakulteta tehničkih nauka, Vol. 25(11), pp. 1859-1862, (2020)

[22] A. Zelić, R. Šostakov, D. Živanić, N. Ilanković, „Non-integrated Working Platforms used in Conjuction with Forklift Trucks - Dilemmas, Answers and Basic Guidance for Design and Use“, Proceedings of the 7th International Conference „Transport and Logistics“, Niš (Serbia), 6th December 2019, pp. 61-64, (2019)

[23] D. Živanić, A. Zelić, N. Ilanković, A. Gajić, „Case Study: Safety Measures for the Belt Feeder Work“, Proceedings of the 15th International Conference „Continous Education - The Basis for Improving Occupational Safety“, Kladovo (Serbia), 18-22 September 2018, pp. 116-121, (2018)

[24] D. Živanić, N. Ilanković, A. Zelić, „Fire Safety Measures in Warehouses“, Proceedings of the 16th International Conference of Occupational Health and Safety, Ohrid (N. Macedonia), 9-12 October 2019, pp. 23-32, (2019)

[25] N. Ilanković, D. Živanić, A. Zelić, „Accidents During Logging Operations in the USA between 1984. and 2018. Concerning Log Loading, Unloading and Transport", Proceedings of the 5th Scientific Conference „Politehnika“, Beograd (Serbia), 13th December 2019, pp. 389-394, (2019)

[26] N. Ilanković, D. Živanić, A. Zelić, „Accidents During Logging Operations in the USA between 1984. and 2018. Concerning Log Loading, Unloading and Transport", Proceedings of the 5th Scientific Conference „Politehnika“, Beograd (Serbia), 13th December 2019, pp. 389-394, (2019)

[27] A. Zelić, R. Šostakov, D. Živanić, N. Ilanković. „A Proposal to Work Out a Regulation on Health and Safety at Work with Cranes“, Proceedings of the 5th Scientific Conference „Politehnika“, Beograd (Serbia), 13th December 2019, pp. 395-398, (2019) 


\section{Problemi u radu trakastih transportera u rečnoj luci RTC Luka Leget}

Dragan Živanić ${ }^{1 *}$, Atila Zelić ${ }^{1}$, Mirko Katona ${ }^{1}$ ${ }^{1}$ Fakultet tehničkih nauka/Departman za mehanizaciju i konstrukciono, Univerzitet u Novom Sadu, Novi Sad (R. Srbija)

$U$ radu je predstavljena studija slučaja pretovara šljunka u RTC Luka Leget u Sremskoj Mitrovici, R. Srbija. Analizirani su problemi koji su doveli do nepravilnog rada transportera korišćenih u pretovaru šljunka sa barži $u$ postrojenje za separaciju. Obuhvatili su aktiviranje sigurnosnog prekidača pogona transportera, kretanje materijala unazad na traci, lom veze zateznog bubnja $i$ osovine itd. Utvrdeno je da nepoznavanje stvarne sile $u$ transportnoj traci dovodi do većine problema i istaknuta je potreba rešenja za ovaj problem. Na kraju su data predložena rešenja kako bi se uspostavio normalan rad postrojenja i sprečili problemi u pretovaru šljunka.

Ključne reči: Trakasti transporteri, Rečna luka, Separacija šljunka 